DOI: 10.24100/MKF.2020.01.19

\title{
a-Hidroxifoszfonátok előállítása, reakciói és biológiai aktivitása
}

\author{
RÁDAI Zita*
}

\section{Szerves Kémia és Technológia Tanszék, Budapesti Müszaki és Gazdaságtudományi Egyetem, Budafoki út $8 ., 1111$ Budapest}

\section{Bevezetés}

Az $\alpha$-hidroxifoszfonátok elsősorban biológiai aktivitásuk miatt tartanak számot nagy érdeklődésre (1. ábra). Egy híres képviselőjük a triklórfon $(O, O$-dimetil-2,2,2-triklór1-hidroxietilfoszfonát) (1), mely 2,2-diklórvinil-dimetilfoszfonát (diklórfosz) (2) formájában fejti ki hatását, mint acetilkolin-észteráz enzim bénító rovarölőszer. ${ }^{1}$ Humán toxicitása miatt napjainkban azonban már nem használják. Az $\alpha$-hidroxifoszfonátok között vannak növényvédőszerek is (3), ${ }^{2}$ más képviselöikröl (4 és 5) pedig bebizonyították, hogy antibakteriális, ${ }^{3,4}$ illetve gombaölö ${ }^{4}$ hatással rendelkeznek. Egyes származékok (6 és 7) antioxidáns tulajdonságát igazolták. ${ }^{5,6} \mathrm{Az} \alpha$-hidroxifoszfonátok citotoxikus hatását a szakirodalomban keveset vizsgálták. ${ }^{7,8}$

Az $\alpha$-hidroxifoszfonátokat leggyakrabban Pudovikreakcióval állítják elő, ami dialkil-foszfit addícióját jelenti oxovegyületre. A szakirodalomban a Pudovik-reakciót rendszerint oldószer nélkül valósították meg, általában bázis katalizátor jelenlétében. ${ }^{9-12}$ A szerzők hangsúlyozták, hogy ezek a módszerek környezetbarát megoldások $\alpha$-hidroxifoszfonátok előállítására, azt azonban nem vették figyelembe, hogy a reakcióelegy feldolgozása, illetve a nyerstermék tisztítása során nagy mennyiségű szerves oldószert használtak fel. Tehát a szakirodalmi módszerek többsége nem nevezhető ,zöld” eljárásnak.9-12
Az $\alpha$-hidroxifoszfonátok nem csak biológiai vonatkozásban érdekesek, hanem szintetikus jelentőségük is van (2. ábra). ${ }^{13,14}$ Részt vehetnek $O$-acilezési, $O$-alkilezési reakciókban, illetve nukleofil szubsztitúcióban. Az OH-csoport redukciója, illetve oxidációja szintén lehetséges. Az észter-csoportok hidrolízisével foszfonsavak nyerhetők. Egy érdekes reakció a foszfa-Brook átrendeződés, melynek során az $\alpha$-hidroxifoszfonát bázis jelenlétében benzil-foszfáttá alakul.

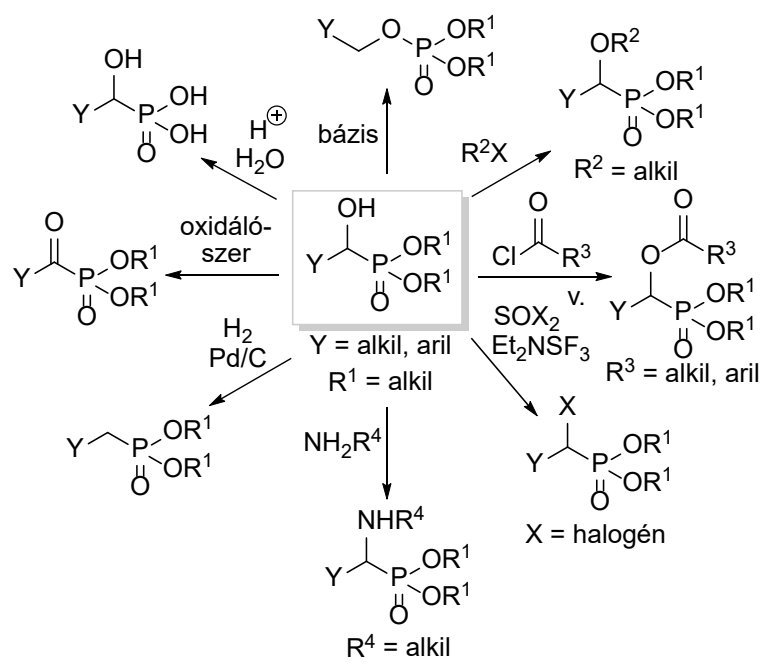

2. Ábra. $\alpha$-Hidroxifoszfonátok, mint értékes kiindulási anyagok.
Enzim inhibitorok (inszekticidek)<smiles>COP(=O)(OC)C(O)C(Cl)(Cl)Cl</smiles>

1<smiles>COP(=O)(OC)OC=C(Cl)Cl</smiles>

2<smiles>CCCOP(=O)(OCCC)C(O)c1ccccc1Oc1nc(OC)cc(OC)n1</smiles>

Antioxidánsok

Citotoxikus hatású vegyület<smiles>CCOP(=O)(OCC)C(O)c1cccc([N+](=O)[O-])c1</smiles>

7

Antibiotikum<smiles>CCOP(=O)(OCC)C(O)c1cnc2ccccc2c1</smiles>
4
Antibakteriális- és gombaölõszer<smiles>CCOP(=O)(OCC)C(O)c1cc2cc(C)ccc2n2nnnc12</smiles>

5<smiles>CCOP(=O)(OCC)C(O)c1c2ccccc2cc2ccccc12</smiles>

6<smiles>CCCCOP(=O)(OCCCC)C(O)c1cc(Cl)ccc1O</smiles>

8

1. Ábra. Válogatott példák biológiailag aktív $\alpha$-hidroxifoszfonátokra. 


\section{Eredmények és értékelésük}

A Tanszéken közel tíz éve foglalkoznak $\alpha$-hidroxifoszfonátok előállításával. Kutatócsoportunkban nagy hagyománya van a mikrohullámú (MW) technika alkalmazásának szerves kémiai reakciókban. Kezdetben a Pudovik-reakciót is MW körülmények között, nátrium-karbonát bázis jelenlétében valósították meg. ${ }^{15}$

Annak ellenére, hogy Kutatócsoportunkban korábban azt tapasztalták, hogy a MW besugárzás számos reakció lejátszódását kedvezően befolyásolta, ${ }^{16-19}$ felismertük, hogy a Pudovik-reakció megvalósításához valójában nincsen szükség sem magas hőmérsékletre, sem MW besugárzásra, a reakció enyhébb körülmények között is lejátszódik. Ezekböl a megállapításokból kiindulva célul tüztük ki egy új variáció kidolgozását a Pudovik-reakcióra. Különleges figyelmet fordítottunk arra, hogy a szerves oldószer-felhasználást tekintve az irodalmi módszereknél zöldebb megoldást találjunk.

\subsection{Egy új, környezetbarát eljárás kidolgozása a-hidroxifoszfonátok előállítására}

Új módszerünk szerint szubsztituált benzaldehid és dialkil-foszfit ekvimoláris elegyét katalitikus mennyiségű trietilamin jelenlétében, kis mennyiségü acetonban forraltuk. A Pudovik-reakció lejátszódása után a reakcióelegyhez egy kicsapó oldószert (pentánt) adtunk. Így hütés hatására a várt termék (9-11) kikristályosodott a reakcióelegyből. Az $\alpha$-hidroxifoszfonátokat (9-11) egy egyszerü szüréssel nagy tisztaságban (>99\%), kiváló (68-99\%) termeléssel kaptuk (3. ábra). ${ }^{20}$

$$
\begin{aligned}
& \text { 1.) } \Delta \\
& \mathrm{Et}_{3} \mathrm{~N}
\end{aligned}
$$

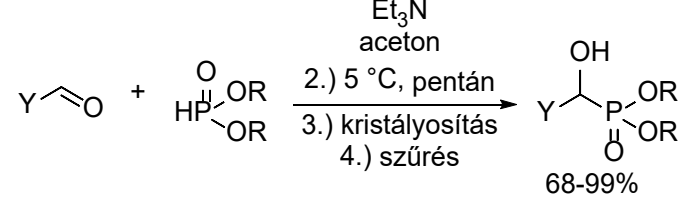

$$
\begin{aligned}
& \mathrm{R}=\mathrm{Me}, \mathrm{Et}, \mathrm{Bn} \\
& \mathrm{Y}=\mathrm{C}_{6} \mathrm{H}_{5}(\mathbf{a}), 3-\mathrm{MeC}_{6} \mathrm{H}_{4}(\mathbf{b}), 4-\mathrm{MeC}_{6} \mathrm{H}_{4}(\mathbf{c}), 2- \\
& \mathrm{MeOC}_{6} \mathrm{H}_{4} \text { (d), 3- } \mathrm{MeOC}_{6} \mathrm{H}_{4}(\mathbf{e}), 3,4-\mathrm{diMeOC}_{6} \mathrm{H}_{3} \text { Et } 10 \\
& \text { (f), 2- } \mathrm{ClC}_{6} \mathrm{H}_{4}(\mathbf{g}), 3-\mathrm{ClC}_{6} \mathrm{H}_{4}(\mathbf{h}), 4-\mathrm{ClC}_{6} \mathrm{H}_{4}(\mathbf{i}), 4-\quad \mathrm{Bn} / 1 \\
& \mathrm{FC}_{6} \mathrm{H}_{4}(\mathrm{j}), 2-\mathrm{NO}_{2} \mathrm{C}_{6} \mathrm{H}_{4}(\mathbf{k}), 4-\mathrm{NO}_{2} \mathrm{C}_{6} \mathrm{H}_{4}(\mathbf{l})
\end{aligned}
$$

3. Ábra. Egy új, környezetbarát variáció a Pudovik-reakcióra.

Új módszerünk fô újdonsága, hogy nem volt szükség a termék utólagos tisztítására, így a szerves oldószer felhasználást a minimumra szorítottuk.

Megállapítottuk, hogy elektronvonzó szubsztituensek az aromás gyürün elősegítették a reakció lejátszódását, míg elektronküldő metil- vagy metoxicsoport jelenlétében hoszszabb reakcióidöre volt szükség, illetve bizonyos esetekben a katalizátor mennyiségét is meg kellett növelni. A foszfitok közül a dimetil-foszfitnak volt a legnagyobb a reaktivitása, amit a dibenzil-, majd dietil-foszfit követett (4. ábra).

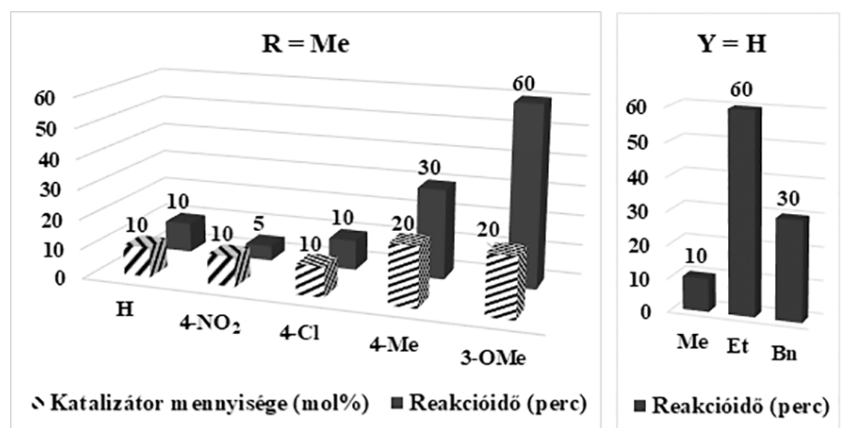

4. Ábra. Az aromás gyürü szubsztituensének, illetve a dialkil-foszfit alkil-csoportjának reaktivitásra gyakorolt hatása.

\subsection{A módszer kiterjesztése ketonok és dialkil-foszfit reakciójára}

Új módszerünket szerettük volna kiterjeszteni ketonok és dialkil-foszfit reakciójára is, azonban azt tapasztaltuk, hogy a ketonok reakciója megköveteli egy ekvivalens trietilamin alkalmazását. A trietilamin azonban ebben a mennyiségben az aceton oldószert is aktiválta, így melléktermékként az aceton és dialkil-foszfit reakciójában keletkezett dimetil-1-hidroxi-1-metiletilfoszfonátot azonosítottuk. Annak érdekében, hogy a melléktermék keletkezését kiküszöböljük, a reakciót megkísérletük acetonitrilben is. Azonban az oldószer és a nagy mennyiségü trietilamin együttes jelenléte a termék (12 és 13) kristályosodását jelentősen megnehezítette.

Az $\alpha$-metil- $\alpha$-hidroxifoszfonátok (12 és 13) előállítására végül az a megoldás született, hogy az addíciót oldószer nélkül hajtottuk végre, így a termék kikristályosodott a reakcióelegyből. Szürés után a kristályokat hexános mosással tisztítottuk (5. ábra). ${ }^{21}$

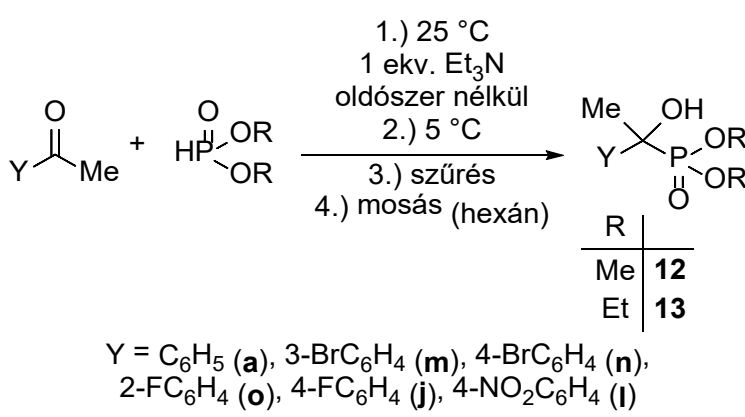

5. Ábra. $\alpha$-Metil- $\alpha$-hidroxifoszfonátok (12 és 13) előállítása.

\subsection{A trietilamin-katalizált Pudovik-reakció energetikai háttere}

Kíváncsiak voltunk a trietilamin szerepére a Pudovikreakcióban, illetve az aldehidek és ketonok közötti reaktivitáskülönbség okára, ezért kvantumkémiai számításokkal (B3LYP/6-31G(d,p)//PCM(THF) elméleti szinten) vizsgáltuk dietil-foszfit és benzaldehid, illetve acetofenon Pudovik-reakciójának mechanizmusát katalizátor nélkül (6. ábra, A útvonal), illetve trietilamin katalizátorral (6. ábra, B útvonal). ${ }^{22}$ A számításokból kiderült, hogy a foszfit tri- 


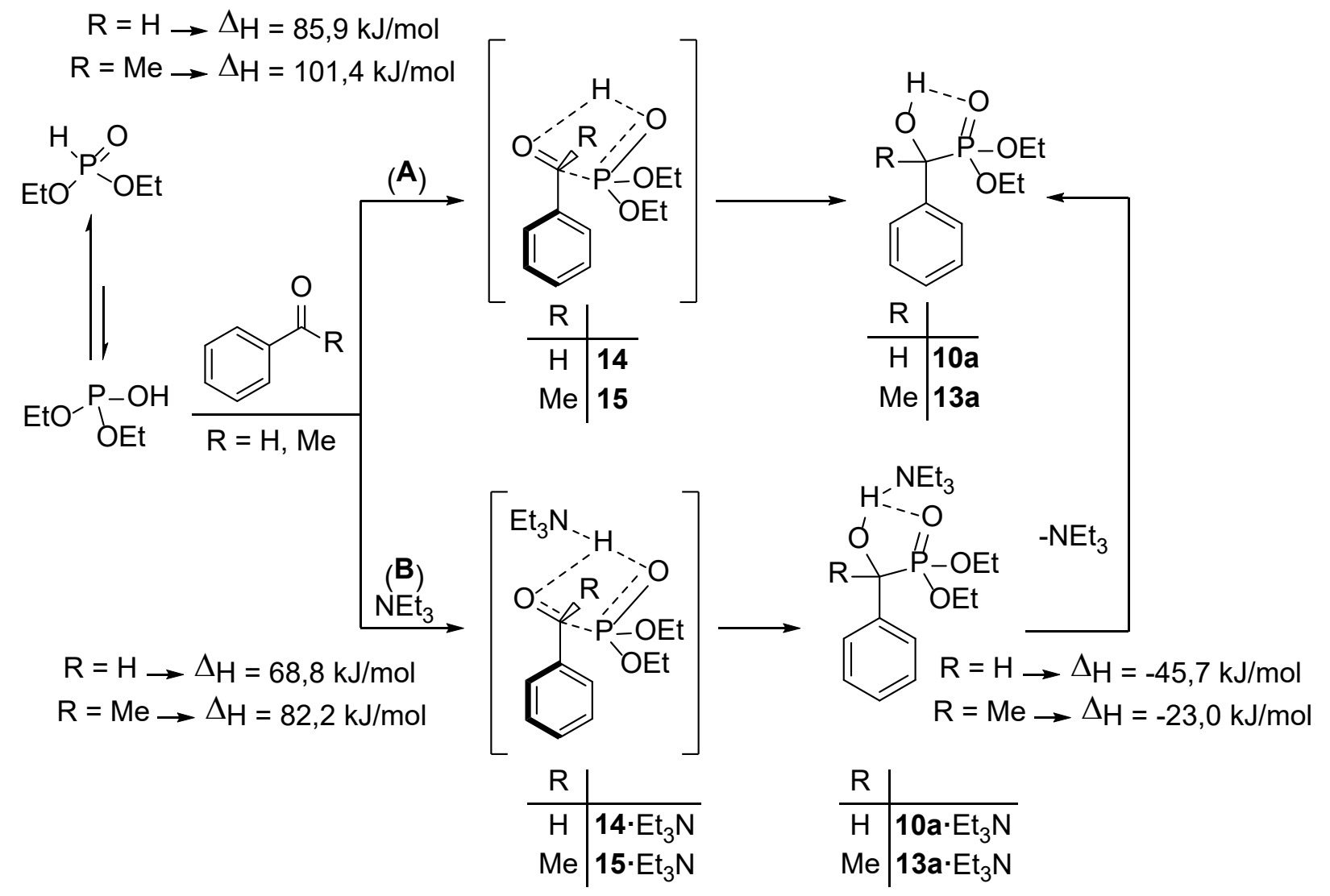

6. Ábra. Benzaldehid, illetve acetofenon és dietil-foszfit Pudovik-reakciójának mechanizmusa katalizátor nélkül (A), illetve trietilamin katalizátorral (B).

valens tautomer formában vesz részt a reakcióban. A trietilamin nem elég erös bázis ahhoz, hogy deprotonálja a foszfitot, azonban kölcsönhatásba lép a foszfit protonjával, így gyengíti a PO-H kötést, ezáltal csökkenti az átmeneti állapot entalpiáját, vagyis katalizálja a reakciót. Ezt a számított $\Delta \mathrm{H}^{\ddagger}$ értékek is alátámasztották: benzaldehidből kiindulva, katalizátor nélkül az aktiválási entalpiagát 85,9 $\mathrm{kJ} / \mathrm{mol}$, míg trietilamin katalizátor jelenlétében ugyanez az érték $68,8 \mathrm{~kJ} / \mathrm{mol}$ (6. ábra).

A számítások alátámasztották azt a megfigyelésünket is, hogy acetofenonból kiindulva a Pudovik-reakció megvalósítása nagyobb kihívást jelent, mint amennyiben benzaldehid a kiindulási oxovegyület. Trietilamin jelenlétében a benzaldehid reakciójának aktiválási entalpiagátja 68,8 kJ/mol, míg acetofenonra ez az érték $82,2 \mathrm{~kJ} / \mathrm{mol}$. Ami a termodinamikát illeti, szintén a benzaldehidből származtatható $\alpha$-hidroxifoszfonát (10a) keletkezése a kedvezőbb (benzaldehid esetében $\Delta \mathrm{H}^{\circ}=$ $-45,7 \mathrm{~kJ} / \mathrm{mol}$, míg 13a keletkezésére $\Delta \mathrm{H}^{\circ}=-23,0 \mathrm{~kJ} / \mathrm{mol}$ ).

\section{4. $\alpha$-Hidroxifoszfonátok szerkezetvizsgálata röntgenkrisztallográfiával}

Hét $\alpha$-hidroxifoszfonátból $(9 \mathrm{a}, 9 \mathrm{f}, 11 \mathrm{c}, 11 \mathrm{~h}, 11 \mathrm{k}, 12 \mathrm{a}$ és 12l) sikerült egykristályokat előállítanunk, így lehetőségünk nyílt a kristályszerkezetük tanulmányozására röntgenkrisztallográfiával. ${ }^{21}$ Megállapítottuk, hogy a kristályrácsban az $\alpha$-hidroxifoszfonát molekulák kétféle rendező elvet követtek. Az $\alpha$-helyzetben hidrogént tartalmazó származékok (9a, 9f, 11c és 11h) kristályrácsában a molekulák láncszerü asszociátumokat képeztek (7. ábra), míg az $\alpha$-metil- $\alpha$-hidroxifoszfonátok esetében (12a és 12l) a monomerek dimerekké álltak össze (8. ábra).
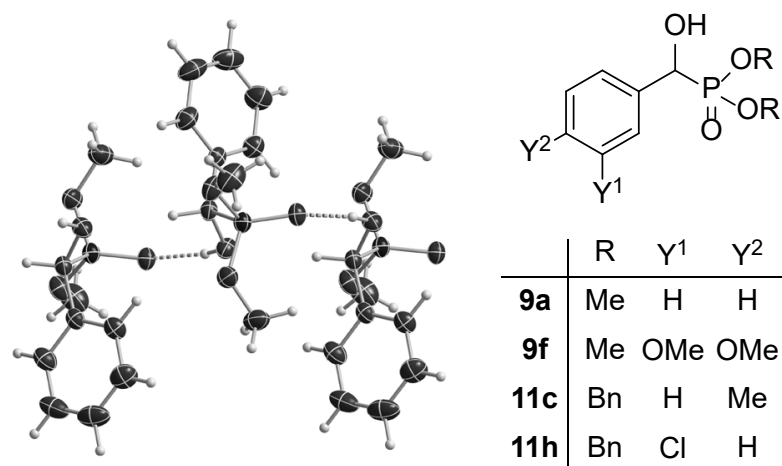

7. Ábra. Lánc-asszociátumokat képző $\alpha$-hidroxifoszfonátok.

Az általunk elöállított származékok között a fenti szabály alól csupán egyetlen kivétel volt. A dibenzil-1-hidroxi-1-(2-nitrofenil)metilfoszfonát (11k) molekulák a kristályrácsban - előzetes várakozásainkkal ellentétben lánc-asszociátumok helyett dimereket alkottak (9. ábra). 

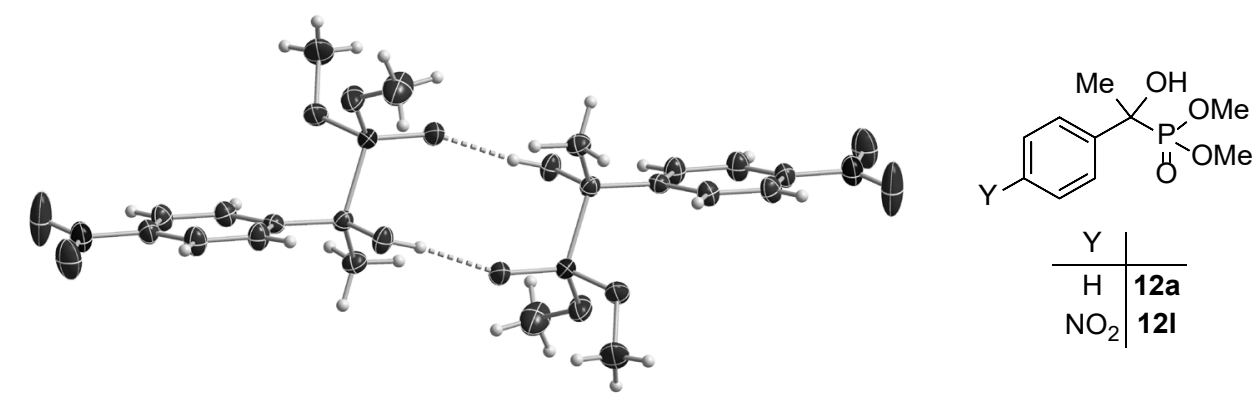

8. ábra. Dimereket képző $\alpha$-hidroxifoszfonátok.

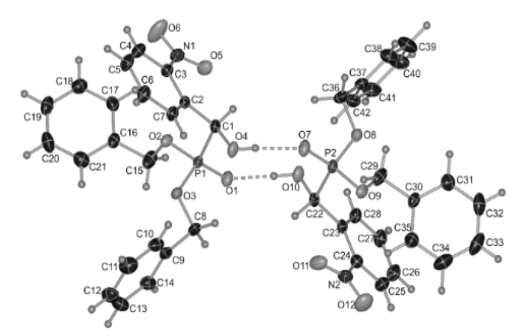<smiles>O=[N+]([O-])c1ccccc1C(O)P(=O)(OCc1ccccc1)OCc1ccccc1</smiles>

$11 \mathrm{k}$

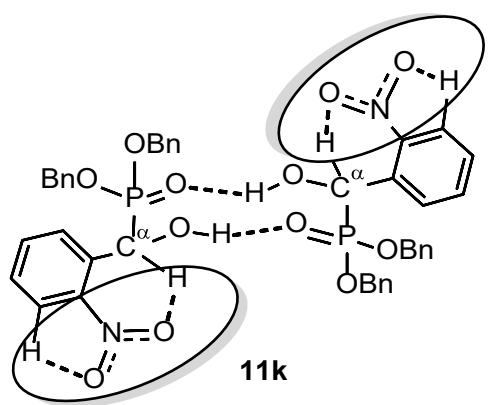

11. Ábra. A kivételt képező 11k molekula kristályrácsában található dimerek.

\section{5. a-Hidroxifoszfonátok továbbalakítása}

Ahogy a Bevezetésben is bemutattam, az $\alpha$-hidroxifoszfonátok rendkívül sokoldalú vegyületek. Továbbalakításukkal számos vegyületcsalád állítható elö, melyek potenciális biológiai aktivitással rendelkeznek.

Az $\alpha$-aciloxifoszfonátok a szakirodalomban növényvédőszerként ismertek. ${ }^{23,24}$ Ezen vegyületek foszfor analogonjaira azonban csak néhány példa található, így kutatómunkám során $\alpha$-hidroxifoszfonátok foszforsav-, illetve foszfinsav-kloridokkal való acilezését kezdtük vizsgálni. ${ }^{25}$

Foszforilezöszerként ciklikus foszfinsav-kloridokat (1-klór-3-foszfolén-1-oxidokat), difenilfoszfinsav-kloridot, illetve egy foszforsav-származékot (difenilfoszforil-kloridot) választottunk. A reakciókat szobahőmérsékleten, toluolban végeztük, trietilamin savmegkötő jelenlétében (12. ábra). Tapasztalataink szerint a ciklikus foszfinsav-kloridok voltak a legreaktívabbak, melyekkel 24 óra alatt lejátszódott a reakció. Difenilfoszfinsav-kloriddal 48 órára volt szükség, míg difenilfoszforil-kloriddal 72 óra után is<smiles>COC(C)(c1ccc([N+](=O)[O-])cc1)P(OC)(OC)(OC)OC</smiles>

10. Ábra. Fő kristályrács összetartó erők a lánc-asszociátumok és dimerek esetében. 
csupán szerény $(\sim 16 \%)$ termeléssel sikerült előállítani a várt termékeket (16D). Ennek oka a foszforsav-származék csökkent reakciókészsége, illetve a termék fokozott hidrolízisre való érzékenysége.

$$
\begin{aligned}
& \text { (26) } \\
& \begin{array}{c|cr|c}
\mathrm{R} & & \mathrm{R} & \\
\hline \mathrm{Me} & 9 & \mathrm{Me} & 16 \\
\mathrm{Bn} & 11 & \mathrm{Bn} & 17
\end{array} \\
& \mathrm{Y}^{1}=\mathrm{H}(\mathbf{a}), 4-\mathrm{Me}(\mathbf{c}), 2-\mathrm{Cl}(\mathbf{g}), 3-\mathrm{Cl} \\
& \text { (h), } 4-\mathrm{Cl}(\mathbf{i}), 2-\mathrm{NO}_{2}(\mathbf{k}), 4-\mathrm{NO}_{2} \text { (I) } \\
& \mathrm{Y}^{2}, \mathrm{Y}^{3}=\mathrm{Ph}_{(\mathbf{A}),}\left\langle{ }_{(\mathbf{B}),}\right\rangle \mathrm{C}_{(\mathbf{C}), \mathrm{OPh}_{(\mathbf{D})}}
\end{aligned}
$$

12. Ábra. $\alpha$-Hidroxifoszfonátok reakciója foszfinsav-, illetve foszforsavkloridokkal.

Az $\alpha$-aminofoszfonátok az $\alpha$-aminosavak foszfor analogonjai, melyek számos biológiai hatásuknak köszönhetően váltak ismertté. ${ }^{26,27} \mathrm{~A}$ vegyületcsalád tagjait emzim inhibitorként, antibiotikumként, vírusellenes, valamint citotoxikus hatású szerként tartják számon. Az $\alpha$-aminofoszfonátokat a szakirodalomban általában oxovegyület, amin és $P$-reagens háromkomponensü reakciójában (Kabachnik-Fields-reakció) állítják elő. ${ }^{28-30}$

Kutatócsoportunkban egy új módszert dolgoztak ki $\alpha$-aminofoszfonátok (18) előállítására, mely szerint dietil-1-hidroxi-1-fenilmetilfoszfonát (10a) és primer aminok reakcióját MW körülmények között, katalizátor és oldószer hozzáadása nélkül valósították meg. ${ }^{30} \mathrm{~A}$ reakciót kiterjesztettük különféle para-helyzetben szubsztituált $\alpha$-aminofoszfonátok (18c, 18p, 18i) elöállítására is (13. ábra). ${ }^{20}$

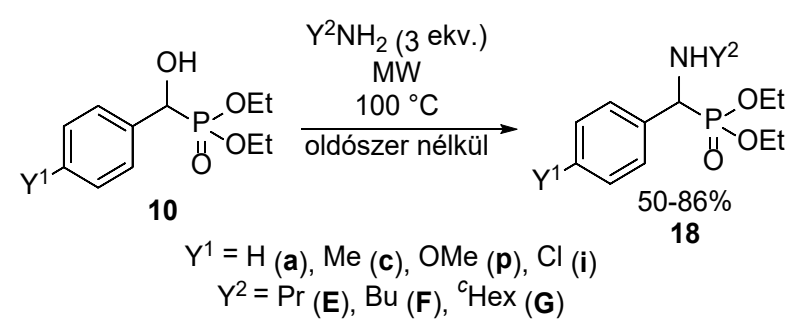

13. Ábra. $\alpha$-Hidroxifoszfonátok (10) reakciója primer aminokkal.

Meglepetésünkre azt tapasztaltuk, hogy a nukleofil szubsztitúció rendkívül rövid idő (10-30 perc) alatt lejátszódik, így kvantumkémiai számításokkal vizsgáltuk a reakció mechanizmusát. ${ }^{22,31}$ A számításokból kiderült, hogy az amin nukleofil támadása $\mathrm{S}_{\mathrm{N}} 2$ mechanizmust követ. A sebességmeghatározó lépés a hidroxi-csoport kilépése az $\alpha$-szénatomról. Ezt a lépést egy kedvező szomszédcsoport hatás segíti, melynek hajtóereje a $\mathrm{P}-\mathrm{O}$ kötés létesülése (14. ábra). Ez a jelenség magyarázatot jelenthet a gyors reakcióra.

Az $\alpha$-hidroxifoszfonsavakat a szakirodalomban általában a megfelelő metil- vagy etil-észter hidrolízisével állítják elö, melyet sokszor nagy savfeleslegben, a reakcióelegy forralásával végeznek, a reakció pedig hosszú órákat vesz igénybe. ${ }^{32,33} \mathrm{Az} \alpha$-hidroxifoszfonsavak (19) előállítására kutatócsoportunkban egy új módszert dolgoztunk ki. ${ }^{34}$ Dibenzil-1-hidroxi-1-arilmetilfoszfonátokat (11) Pd/C katalizátor jelenlétében katalitikus hidrogénezéssel alakítottuk hidroxifoszfonsavakká (19) (15. ábra). A módszer előnye, hogy a debenzilezés a hidrolízisekkel szemben szobahömérsékleten, rövid idő alatt lejátszódott, így ez egy jó alternatíva az erélyes körülmények között végzett hidrolízisekre. Egyetlen hátrányként a csökkent atomhatékonyság említhető.

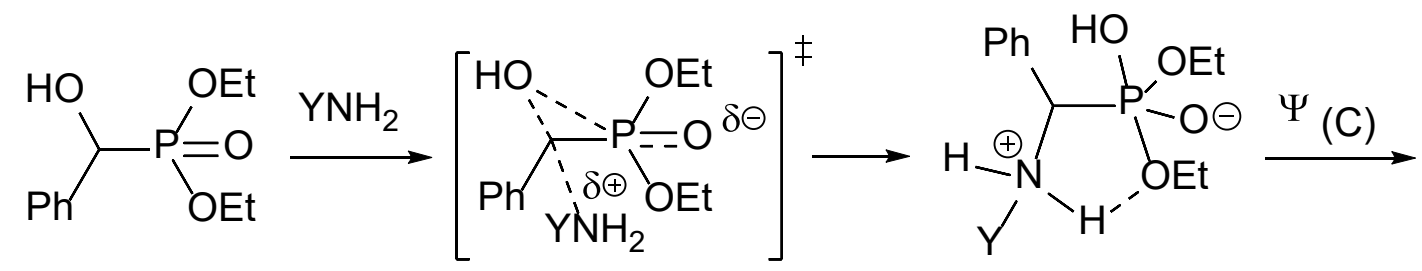

$Y=$ alkil, aralkil

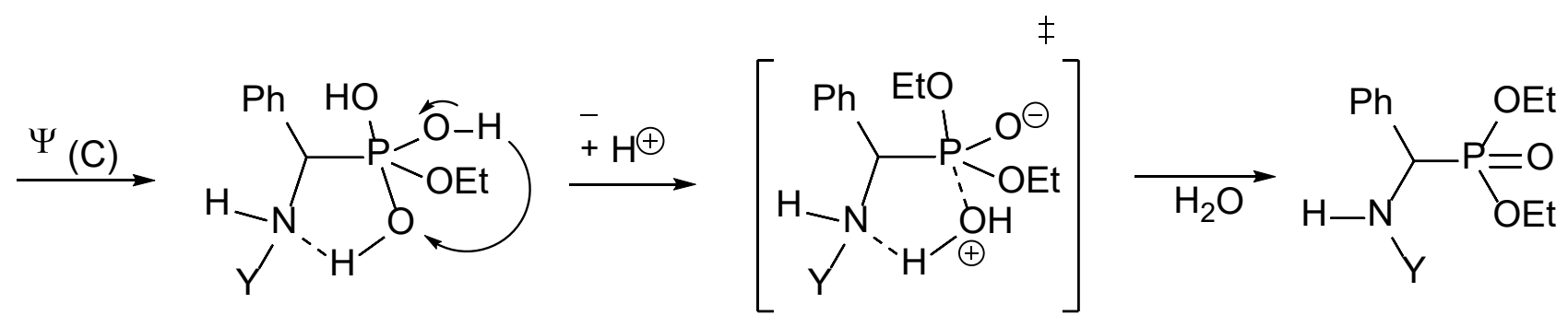

14. Ábra. Kedvező szomszédcsoport hatás $\alpha$-hidroxifoszfonátok és primer aminok reakciója során. 


$$
\begin{aligned}
& \text { MeOH } \\
& 11 \\
& \mathrm{Y}=\mathrm{H}(\mathbf{a}),{ }^{3}-\mathrm{Me}(\mathbf{b}), \text { 4-Me (c), } 2-\mathrm{MeO}(\mathbf{d}),{ }^{2}-\mathrm{Cl}(\mathbf{g}) \text {, } \\
& 3-\mathrm{Cl}_{(\mathbf{h}),}, 4-\mathrm{Cl} \text { (i), } 4-\mathrm{NO}_{2} \text { (I) }
\end{aligned}
$$

15. Ábra. Dibenzil- $\alpha$-hidroxifoszfonátok (11) katalitikus hidrogénezése.

\section{6. $\alpha$-Hidroxifoszfonátok és származékaik citotoxicitás vizsgálata}

Mivel az $\alpha$-hidroxifoszfonátok és származékaik jelentősége elsősorban biológiai aktivitásukban rejlik, célul tüztük ki az általunk előállított vegyületkönyvtár biológiai hatásának feltérképezését. Az $\alpha$-hidroxifoszfonátok citotoxicitását korábban keveset vizsgálták, ${ }^{7,8}$ így vegyületeinket Mes-Sa mCherry és Mes-Sa/Dx5 mCherry humán rákos sejtvonalakon teszteltük, mint potenciális tumorelleni hatóanyagok. Először egy előszürést végeztünk, melynek során több, mint hatvan $\alpha$-hidroxifoszfonátot (9-11), $\alpha$-foszforiloxifoszfonátot (16 és 17), $\alpha$-aminofoszfonátot (18), valamint $\alpha$-hidroxifoszfonsavat (19) teszteltünk $20 \mu \mathrm{M}$, illetve 200 $\mu \mathrm{M}$ koncentrációban. Toxikusnak azokat a vegyületeket nyilvánítottuk, melyek az adott koncentrációban a sejtek minimum $50 \%$-át elpusztították.

A mérések szerint $20 \mu \mathrm{M}$ koncentrációban egyik vegyület sem bizonyult toxikusnak a vizsgált sejtvonalakkal szemben, azonban $200 \mu \mathrm{M}$ koncentrációban a dibenzil-1-hidroxi-1-arilmetilfoszfonátok $(\mathbf{1 1})^{34}$ és a difenilfoszfinoil egységet tartalmazó $\alpha$-foszfinoiloxifoszfonátok (16A) hatá- sosnak bizonyultak, így ezeknek a származékoknak meghatároztuk az $\mathrm{IC}_{50}$ értékét. Azok a vegyületek, melyek a dibenzil-foszfonát és az $\alpha$-difenilfoszfinoiloxi egységet is tartalmazták (17A) fokozott aktivitást $\left(\mathrm{IC}_{50} \sim 10 \mu \mathrm{M}\right)$ mutattak (16. ábra).

Az $\alpha$-hidroxifoszfonátok és származékaik citotoxicitás vizsgálata során elért eddigi eredményeink biztatóak, ezért vegyületkönyvtárunkat további humán rákos sejtvonalakon is vizsgáljuk.

\section{3. Összefoglalás}

Doktori kutatómunkám $\alpha$-hidroxifoszfonátok előállítását, illetve továbbalakítási lehetőségeinek vizsgálatát célozta. Először egy új módszer dolgoztunk ki $\alpha$-hidroxifoszfonátok előállítására, melynek fő újdonsága, hogy a kémiai reakciót a reakcióelegyből történő kristályosítás követte, így az $\alpha$-hidroxifoszfonátokat nagy tisztasággal kaptuk. Az utólagos tisztítás elkerülhetővé vált, a szerves oldószer-felhasználást pedig csökkenteni tudtuk az irodalmi módszerekhez képest. Kísérleteink során azt tapasztaltuk, hogy a ketonok a benzaldehidekhez képest csökkent reakciókészségüek a Pudovik-reakcióban. Ezt a jelenséget kvantumkémiai számításaink is alátámasztottuk. Az általunk elöállított $\alpha$-hidroxifoszfonátok kristályszerkezetét röntgen-krisztallográfiával vizsgáltuk. Magyarázatot adtunk arra, hogy az $\alpha$-metil- $\alpha$-hidroxifoszfonátok dimereket képeznek, míg a benzaldehidből származtatható $\alpha$-hidroxifoszfonátok kristályrácsában lánc-asszociátumok találhatók. Az $\boldsymbol{\alpha}$-hidroxifoszfonátokat különféle reakciókban hasznosítottuk, így új reakcióutakat dolgoztunk ki. $\alpha$-Hidroxi-<smiles>[Y][Y]1ccc(C(OP(=O)(c2ccccc2)c2ccccc2)P(=O)(OC)OCc2ccccc2)cc1</smiles>

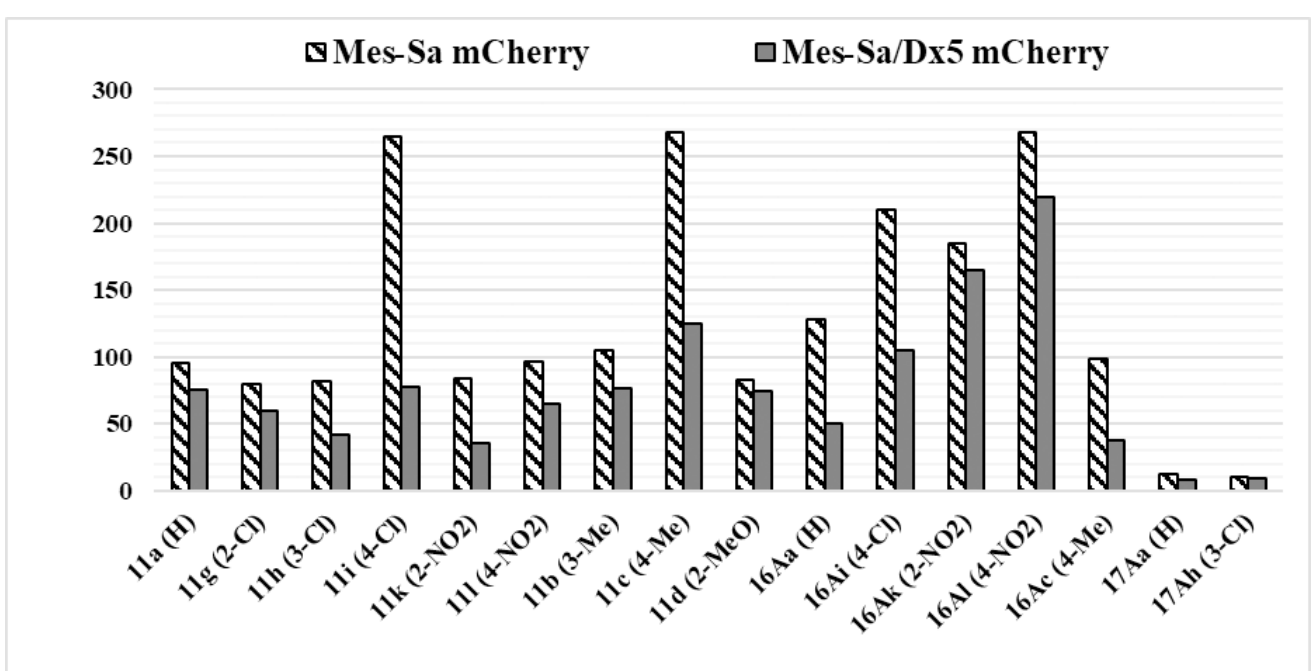

16. Ábra. $\alpha$-Hidroxifoszfonátok és a belőlük képzett citotoxikus származékok $\mathrm{IC}_{50}$ értéke Mes-Sa mCherry és Mes-Sa/Dx5 mCherry rákos sejtvonalakon (zárójelben az aromás gyürü szubsztituensét jelöltem). 
foszfonátok és foszfortartalmú savkloridok reakciójával új, korábban nem ismert vegyületcsaládokat tettünk hozzáférhetővé. A hidroxi-csoport nukleofil szubsztitúciója primer aminokkal $\alpha$-aminofoszfonátokat eredményezett. A dibenzil-1-hidroxi-1-arilmetilfoszfonátok katalitikus hidrogénezésével pedig $\alpha$-hidroxifoszfonsavakhoz jutottunk. Végül az általunk előállított vegyületkönyvtár citotoxikus hatását vizsgáltuk, melynek során találtunk biológiai aktivitást mutató, ígéretes hatóanyagokat.

\section{Köszönetnyilvánítás}

Köszönettel tartozom Dr. Keglevich György témavezetőmnek és Dr. Kiss Nóra Zsuzsa konzulensemnek munkám során nyújtott segítségükért. Köszönöm Dr. Mucsi Zoltánnak a kvantumkémiai számításokban nyújtott segítségét. Dr. Hegedűs Lászlónak a katalitikus hidrogénezések során nyújtott segítségéért tartozom hálával. A citotoxicitás vizsgálatokat az MTA-TTK Enzinológia Intézet munkatársai, Tóth Szilárd, Windt Tímea, Nagy Veronika és Füredi András végezték. A kutatás a Nemzeti Kutatási Fejlesztési és Innovációs Alap (K119202) támogatásával valósult meg. $\mathrm{Az}$ Emberi Erőforrások Minisztériuma ÚNKP-18-3-IVBME-265 kódszámú Új Nemzeti Kiválóság Programjának támogatásával készült.

\section{Hivatkozások}

1. Lorenz, W.; Henglein, A.; Schrader, G. J. Am. Chem. Soc. 1955, 77, 2554-2556. https://doi.org/10.1021/ja01614a061

2. Song, H.; Mao, H.; Shi, D. Chin. J. Chem. 2010, 28, 20202024. https://doi.org/10.1002/cjoc.201090337

3. Pokalwar, R. U.; Hangarge, R. V.; Maske, P. V.; Shingare, M. S. Arkivoc 2006, 11, 196-204. https://doi.org/10.3998/ark.5550190.0007.b20

4. Kategaonkar, A. H.; Pokalwar, R. U.; Sonar, S. S.; Gawali, V. U.; Shingate, B. B.; Shingare, M. S. Eur. J. Med. Chem. 2010, 45, 1128-1132. https://doi.org/10.1016/j.ejmech.2009.12.013

5. Rao, K. U. M.; Sundar, C. S.; Prasad, S. S.; Rani, C. R.; Reddy, C. S. Bull. Korean Chem. Soc. 2011, 32, 3343-3347. https://doi.org/10.5012/bkcs.2011.32.9.3343

6. Naidu, K. R. M.; Kumar, K. S.; Arulselvan, P.; Reddy, C. B.; Lasekan, O. Arch. Pharm. Chem. Life Sci. 2012, 345 , 957-963. https://doi.org/10.1002/ardp.201200192

7. Kalla, R. M. N.; Lee, H. R.; Cao, J.; Yoo, J. W.; Kim, I. New J. Chem. 2015, 39, 3916-3922. https://doi.org/10.1039/C5NJ00312A

8. Lewkowski, J.; Moya, M. R.; Wrona-Piotrowicz, A.; Zakrzewski, J.; Kontek, R.; Gajek, G. Beilstein J. Org. Chem. 2016, 12, 1229-1235. https://doi.org/10.3762/bjoc. 12.117

9. Nandre, K. P.; Nandre, J. P.; Patil, V. S.; Bhosale, S. V. Chem. Biol. Interface 2012, 2, 314-321. Nincs DOI

10. Kumar, K. S.; Reddy, C. B.; Reddy, M. V. N.; Rani, C. R.; Reddy, C. S. Org. Commun. 2012, 5, 50-57. Nincs DOI

11. Aouani, I.; Lahbib, K.; Touil, S. Medicinal Chem. 2015, 11, 206-213.

https://doi.org/10.2174/1573406410666140706154046
12. Ramananarivo, H. R.; Solhy, A.; Sebti, J.; Smahi, A.; Zahouily, M.; Clark, J.; Sebti, S. ACS Sustain. Chem. Eng. 2013, 1, 403-409. https://doi.org/10.1021/sc3001417

13. Sobhani, S.; Tashrifi, Z. Tetrahedron 2010, 66, 1429-1439. https://doi.org/10.1016/j.tet.2009.11.081

14. Rádai, Z.; Keglevich G. Molecules 2018, 23, 1493-1522. https://doi.org/10.3390/molecules23061493

15. Keglevich, G.; Tóth, V. R.; Drahos, L. Heteroatom Chem. 2011, 22, 15-17. https://doi.org/10.1002/hc.20649

16. Kiss, N. Z.; Ludányi, K.; Drahos, L.; Keglevich, G. Synthetic Commun. 2009, 39, 2392-2404. https://doi.org/10.1080/00397910802654880

17. Keglevich, G.; Grün, A.; Bálint, E. Curr. Org. Synth. 2013, 10,751-763. https://doi.org/10.2174/1570179411310050006

18. Bálint, E.; Tajti, Á.; Tripolszky, A.; Keglevich, G. Russ. J. Gen. Chem. 2009, 79, 1480-1485. https://doi.org/10.3390/ecsoc-21-04716

19. Keglevich, G.; Grün, A.; Bölcskei, A.; Drahos, L.; Kraszni, M.; Balogh, G. T. Heteroatom Chem. 2012, 23, 574-582. https://doi.org/10.1002/hc.21053

20. Keglevich, G.; Rádai, Z.; Kiss, N. Z. Green Process. Synth. 2017, 6, 197-201. https://doi.org/10.1107/S2053229619001839

21. Rádai, Z.; Kiss, N. Z.; Czugler, M.; Karaghiosoff, K.; Keglevich, G. Acta Crystallogr. C 2019, C75, 283-293. https://doi.org/10.1107/S2053229619001839

22. Kiss, N. Z.; Rádai, Z.; Mucsi, Z.; Keglevich, G. Heteroatom Chem. 2016, 27, 260-268. https://doi.org/10.1002/hc.21324

23. Chen, X. B.; Shi, D. Q., Phosphorus Sulfur Silicon Relat. Elem. 2008, 183, 1134-1144. https://doi.org/10.1080/10426500701578522

24. Soung, M. G.; Kim, J. H.; Kwon, B. M.; Sung, N. D., Bull. Korean Chem. Soc. 2010, 31, 1355-1360. https://doi.org/10.5012/bkcs.2010.31.5.1361

25. Rádai, Z.; Hodula, V.; Kiss, N. Z.; Kóti, J.; Keglevich, G. Mendeleev Commun. 2019, 29, 153-154. https://doi.org/10.1016/j.mencom.2019.03.011

26. Demkowicz, S.; Rachon, J.; Daśko, M.; Kozak, W., RSC Adv. 2016, 6, 7101-7112. https://doi.org/10.1039/C5RA25446A

27. Kafarski, P.; Lejczak, B., Curr. Med. Chem. - Anti-Cancer Agents. 2001, 1, 301-312. https://doi.org/10.2174/1568011013354543

28. Keglevich, G.; Bálint, E.; Keglevich, G.; Bálint, E., Molecules. 2012, 17, 12821-12835. https://doi.org/10.3390/molecules 171112821

29. Zefirov, N. S.; Matveeva, E. D., Arkivoc. 2008, 2008, 1-17. https://doi.org/10.3998/ark.5550190.0009.101

30. Kafarski, P.; Górny Vel Górniak, M.; Andrasiak, I., Curr. Green Chem. 2015, 2, 218-222. https://doi.org/10.2174/2213346102666150109203606

31. Kiss, N. Z.; Kaszás, A.; Drahos, L.; Mucsi, Z.; Keglevich, G. Tetrahedron Lett. 2012, 53, 207-209. https://doi.org/10.1016/j.tetlet.2011.11.026

32. Forlani, G.; Occhipinti, A.; Berlicki, Ł.; Dziedzioła, G.; Wieczorek, A.; Kafarski, P., J. Agric. Food Chem. 2008, 56, 3193-3199. https://doi.org/10.1021/jf800029t

33. Nesterov, V. V.; Kolodiazhnyi, O. I., Tetrahedron. 2007, 63, 6720-6731. https://doi.org/10.1016/j.tet.2007.04.101

34. Rádai, Z.; Szeles, P.; Kiss, N. Z.; Hegedüs, L.; Windt, T.; Nagy, V.; Keglevich, G. Heteroatom Chem. 2018, e21436. https://doi.org/10.1002/hc.21436 


\section{Synthetic and biological importance of $\alpha$-hydroxyphosphonates}

$\alpha$-Hydroxyphosphonates have attracted attention due to their biological activity as enzyme inhibitors, ${ }^{1}$ herbicides, ${ }^{2}$ antiviral agents, ${ }^{3,4}$ as well as fungicides ${ }^{4}$ and antioxidants. ${ }^{5,6}$ So far, only a few studies reported the investigation of $\alpha$-hydroxyphosphonates as potential cytotoxic agents (Scheme 1).,8

$\alpha$-Hydroxyphosphonates are also important starting materials. By the transformation of the $\alpha$-hydroxy function, $O$-alkoxyphosphonates and $O$-acyloxyphosphonates may be synthesized. The hydroxy function can also take part nucleophilic substitutions, reductions or oxidations. The hydrolysis of the ester functions results in $\alpha$-hydroxyphosphonic acids (Scheme 2). ${ }^{13,14}$

The most commonly applied synthetic route towards $\alpha$-hydroxyphosphonates is the Pudovik reaction that involves the addition of a dialkyl phosphite to an oxo compound (aldehyde or ketone), usually in the presence of a base catalyst. The authors of the articles often emphasize the "greenness" of their methods. However, the huge solvent consumption during the work-up and purification process is disregarded that makes these procedures less environmentally friendly. ${ }^{9-12}$

MW technique has been successfully used to enhance a number of different reactions in our research group. ${ }^{16-19}$ The Pudovik reaction has also been carried out under MW conditions. ${ }^{15}$ However, we realized that this reaction does not require harsh conditions and MW irradiation.

On the basis of these recognitions, we aimed at rationalizing the Pudovik reaction from a green chemical point of view. According to our new method, an equimolar mixture of a substituted benzaldehyde and a dialkyl phosphite was stirred in a minimal amount of acetone in the presence of triethylamine as the catalyst. After adding some pentane to the reaction mixture, the desired product (9-11) crystallized out on cooling. $\alpha$-Hydroxyphosphonates $(9-$ 11) were obtained after a simple filtration in high purity $(>99 \%)$ and high yields (68-99\%) (Scheme 3). ${ }^{20}$ The main novelty of this new method is the unnecessity of further purification steps; thus, we managed to reduce the use of organic solvents to the minimum.

It was found that benzaldehydes possessing electron withdrawing substituents facilitated the reaction. Among the phosphorus reagents, dimethyl phosphite was the most reactive, followed by dibenzyl and then diethyl phosphite (Scheme 4).

The reaction was also attempted starting from ketones. However, that reaction required the use of one equivalent of triethylamine. The catalyst in such a huge amount activated the acetone solvent in the reaction leading to the formation of dimethyl 1-hydroxy-1-methylethylphosphonate. As a solution, the Pudovik reaction of ketones was carried out under solvent-free conditions and the product (12 or 13) was purified with hexane (Scheme 5). ${ }^{21}$

The mechanism of the Pudovik reaction was investigated by DFT calculations. ${ }^{22}$ It was found that triethylamine is not a base strong enough to deprotonate the phosphite, but it is able to facilitate the reaction by weakening the $\mathrm{PO}-\mathrm{H}$ bond in the trivalent tautomer form of the dialkyl phosphite. The calculations also indicated that starting from benzaldehyde, the reaction is more favorable than starting from acetophenone from kinetic as well as thermodynamic point of view (Scheme 6).

The crystal structure of seven $\alpha$-hydroxyphosphonates $(\mathbf{9 a}, \mathbf{9 f}, \mathbf{1 1 c}$, $11 \mathrm{~h}, 11 \mathrm{k}, 12 \mathrm{a}$ and 12l) was investigated by $\mathrm{X}$-ray diffraction measurements. ${ }^{21}$ We observed that the molecules of $\alpha-H$ - $\alpha$-hydroxyphosphonates (9a, 9f, 11c and 11h) formed chain-like associates (Scheme 7), while in the crystal structure of $\alpha$-methyl- $\alpha$-hydroxyphosphonates (12a and 12I) dimers could be found (Scheme 8). Only dibenzyl 1-hydroxy-1-(2-nitrophenyl)methylphosphonate (11k) did not fit in the above rule, as instead of chain-like associates, dimers constructed the crystal structure (Scheme 9). To understand this phenomenon, we investigated the main associations constructing the crystal lattice. In all cases, $\mathrm{P}=\mathrm{O} \cdots \mathrm{H}-\mathrm{O} H$-bond between the neighboring molecules was found as the main interaction. In the crystal structure of $\alpha-H$ containing derivatives (9a, 9f, 11c and 11h), a secondary $\mathrm{C}^{\alpha}-\mathrm{H} \cdots \mathrm{O}-\mathrm{C}^{\alpha} H$-bond also occurred (Scheme 10 ). The presence of both types of interactions resulted in the formation of chain-like associates. In case of hydroxyphosphonates lacking the $\alpha-H(9 \mathbf{a}, 9 \mathbf{f}, 11 \mathbf{c}$ and $11 \mathbf{h})$ the secondary interaction could not occur, thus only dimers could be formed. In the molecules of the exception dibenzyl 1-hydroxy-1-(2-nitrophenyl)-methylphosphonate $(11 \mathbf{k})$ the ortho-nitro function shielded the $\alpha-H$. As a consequence, it could not take part in the $\mathrm{C}^{\alpha}-\mathrm{H} \cdots \mathrm{O}-\mathrm{C}^{\alpha}$ bond, accordingly the monomers formed dimers (Scheme 11).

$\alpha$-Hydroxyphosphonates are versatile compounds. Besides their biological properties, they can be transformed to a series of different derivatives that may also possess biological activity.

$\alpha$-Acyloxyphosphonates are known as herbicides in the literature. ${ }^{23,24}$ However, the synthesis of $\alpha$-phosphoryloxyphosphonates is a new field. We performed the phosphinoylation and phosphorylation of $\alpha$-hydroxyphosphonates to obtain new $\alpha$-phosphinoyloxyphosphonates (16A, 16B and 16C) and $\alpha$-phosphoryloxyphosphonates (16D) (Scheme 12). ${ }^{25}$

$\alpha$-Aminophosphonates are of importance due to their biological activity. ${ }^{26,27}$ These compounds are usually synthesized through the Kabachnik-Fields reaction, the three-component condensation of an oxo compound, an amine and a phosphorus reagent. ${ }^{28-30}$ The reaction of $\alpha$-hydroxyphosphonates with primary amines is an alternative way of synthesis. In our research group, a new method has been elaborated for the synthesis of $\alpha$-aminophosphonates (18) from $\alpha$-hydroxyphosphonates (10) under MW irradiation without the use of any catalyst or solvent (Scheme 13). ${ }^{22,31}$ To our surprise, the reaction took place within a short (10-30 $\mathrm{min})$ reaction time, thus the mechanism was investigated by DFT calculations. It was found that the nucleophilic attack of the primary amine to the hydroxyphosphonate (10) follows a $\mathrm{S}_{\mathrm{N}} 2$ mechanism. The reaction is facilitated by a favorable neighboring group effect (Scheme 14). ${ }^{22,31}$

$\alpha$-Hydroxyphosphonic acids are usually synthesized through the hydrolysis of the corresponding methyl or ethyl ester in acidic conditions under reflux. ${ }^{32,33}$ As an alternative route, we performed the catalytic hydrogenation of dibenzyl 1-hydroxy-1-arylmethylphosphonates (11), which afforded $\alpha$-hydroxyphosphonic acids (19) in 5-150 min at ambient temperature (Scheme 15). ${ }^{34}$

The cytotoxic activity of $\alpha$-hydroxyphosphonates has only been investigated in a few articles so far. ${ }^{7,8}$ This motivated us to screen our chemical library against two human cancer cell lines, Mes-Sa mCherry and Mes-Sa/Dx5. During the primary screen we selected the potent derivatives from more than sixty molecules including $\alpha$-hydroxyphosphonates (9-11), $\alpha$-phosphinoyloxyphosphonates (16A, 16B and 16C), $\alpha$-phosphoryloxyphosphonates (16D), $\alpha$-aminophosphonates (18) and $\alpha$-hydroxyphosphonic acids (19). First, the compounds were tested in concentrations of $20 \mu \mathrm{M}$ and 200 $\mu \mathrm{M}$. Toxicity was defined as at least $50 \%$ growth inhibition compared to the untreated cells. During the primary screen, dibenzyl 1-hydroxy-1-arylmethylphosphonates (11) and $\alpha$-phosphinoyloxyphosphonates containing the diphenylphosphinoyl moiety (16A) proved to be the most potent cytotoxic agents. For these types of compounds, $\mathrm{IC}_{50}$ values were determined. Derivatives containing both the dibenzyl phosphonate and the diphenylphosphinoyl moiety (17A) expressed increased toxicity $\left(\mathrm{IC}_{50} \sim 10 \mu \mathrm{M}\right)$ against the investigated cell lines (Scheme 16). 